Şırnak Üniversitesi

Ilahiyat Fakültesi Dergisi

Sayı 27 Aralık 2021

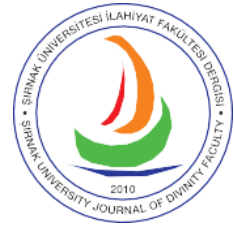

e-ISSN 2667-6575
Şırnak University

Journal of Divinity Faculty

Issue 27 December 2021

\title{
19. Yüzyılda Hâlidîliğin Şark Medreselerine Tesirleri
}

The Effects of Khâlidiyya on Eastern Madrasahs in the 19th Century

\section{Abdulcebbar KAVAK}

Doç. Dr., Karabük Üniversitesi, İslami İlimler Fakültesi, Siyer-i Nebi ve İslam Tarihi Ana Bilim Dalı Associate Professor, Karabük University, Faculty of Divinity, Department of Siyer-i Nebi and History of Islam

Karabük, Turkey

akavak@karabuk.edu.tr

https://orcid.org/0000-0002-1846-5493

\section{Makale Bilgisi / Article Information}

Makale Türü / Article Types: Araştırma Makalesi / Research Article

Geliş Tarihi / Received: 18 Eylül / September 2021

Kabul Tarihi / Accepted: 21 Kasim / November 2021

Yayın Tarihi / Published: 15 Aralık / December 2021

Say1 / Issue: 27 Sayfa / Pages: 5-24

Atıf / Cite as: Kavak, Abdulcebbar. "19. Yüzyılda Hâlidîliğin Şark Medreselerine Tesirleri [The Effects of Khâlidiyya on Eastern Madrasahs in the 19th Century]". Şırnak Üniversitesi İlahiyat Fakültesi Dergisi Şırnak University Journal of Divinity Faculty 27 (December 2021), 5-24. https://doi.org/10.35415/sirnakifd.997360

Etik Beyanı / Ethics Declaration: Bu makalede bilimsel araştırma ve yayın etiği ilkelerine riayet edilmiştir. Makale etik izin gerektirmeyen bir çalışma olup en az iki hakem tarafından incelenmiş ve intihal içermediği teyit edilmiştir./ In this article, the principles of scientific research and publication ethics are respected. The article is a study that does not require ethical permission. It has been reviewed by at least two referees and was confirmed that it did not contain plagiarism.

Copyright $\odot$ Published by Şırnak Üniversitesi, İlahiyat Fakültesi / Şırnak, Türkiye (Şırnak University, Faculty of Divinity, Şırnak, 73000 Turkey). 


\section{Özet}

İslam dünyasındaki en yaygın tarikatlardan biri Nakşibendîliktir. Bu tarikatın 19. yüzyılda Ortadoğu'daki en aktif temsilcisi ise Mevlânâ Hâlid-i Bağdadî'dir. Ona nisbet edilen Hâlidiyye kolu, dinamik yapısıyla toplumsal hayatı canlandıran bir tasavvufî ihya hareketi olarak ortaya çıkmıştır. Hâlidîliğin faaliyetleri içinde en çok öne çıkanlardan biri medreselerin ihyasıdır. Hâlidîliğin ilk olarak Irak'ın Şehrezor bölgesi ile İran ve Anadolu'da yaşayan Kürtler arasında yayılmaya başladığı düşünüldüğünde, ilim ve tedrisat olarak ilk el attığı kurumlar Şark Medreseleri olmuştur. Bu medreseler, Türkiye'de Doğu ve Güneydoğu Anadolu bölgeleri, Irak ve Suriye'nin kuzey bölgeleri ile İran'ın batı bölgeleri gibi özellikle Kürt nüfusun yoğunluklu olduğu geniş bir coğrafyada kurulan ilim merkezleridir. Şark Medreseleri, vakfiyesinde Şâfîler için yaptırıldığ1 vurgulanan ve müderrisler dahil bütün çalışanlarının Şâfiî mezhebine mensup kişilerden seçilmesi şart koşulan Bağdat Nizamiye Medresesi'nin devamı niteliğinde faaliyet yürütmüştür. İmadiye bölgesindeki Kubbehân Medresesi, Erbil'de bulunan Maveran Medresesi, Hevraman bölgesinde bulunan Biyâre Medresesi, Van'ın Müküs (Bahçesaray) ilçesinde bulunan Arvas Medresesi, Muş'un Bulanık ilçesinde bulunan Şeyh Aynü'l-Melek Zaviye ve Medresesi gibi köklü medreselerin dişındakiler, cami bitişiğinde inşa edilen basit yapılardan oluşmuştur. Tedrisatın çoğunlukla müderris merkezli olduğu Şark Medreselerinde, medreseler arası talebe sirkülasyonu fazla olmuştur. Talebelerin yatılı olarak kalabildiği bu ilim merkezlerinde, müfredat olarak Bağdat Nizamiye Medresesi ile kısmen Osmanlı dönemi medreselerinin ders programları takip edilmiştir. Şark Medreselerinde, Arapça ve dinî ilimlerin yanında edebiyat alanında Farsça bazı klasik eserler tercih edilmiştir. Şark Medreselerinde müderrisler dersleri Kürtçe anlatmış, öğrenciler de kendi aralarında müzakere ve okumaları Kürtçe yapmışlardır. Hâlidîlik, ilmi ve medreseyi önceleyen tavrı ile Şark Medreselerinin niceliğini arttırmış ve ayrı bir dinamizm kazandırmıştır. Hâlidîler bir taraftan mevcut medreseleri daha aktif hale getirirken, diğer taraftan pek çok yeni medresenin açılmasını sağlamışlardır. Bu durum bölgenin ilim ve kültür hayatına önemli katkılar sunduğu gibi entelektüel bir tabakanın oluşmasında da öncü rol oynamıştır. Bu ilim merkezlerinde toplumun ihtiyacı olan yönetici, âlim, müderris, siyasetçi, yazar ve şairler yetişmiş ve yaşadıkları dönem bu alanlarda önemli bir açığı kapatmıştır. Hâlidî tekkeleri, şehirlerden kırsala doğru gittikçe yerini medreselere yahut camilere bitişik mütevazı hücrelere bırakmıştır. Hâlidîliğ in yayılmasıyla beraber Şark medreselerinde eğitim ve öğretim işini uhdesine alan müderrisler aynı zamanda irşad görevini de üstlendiklerinden müderris- sûfî modeli ilmiye sınıfı arasında büyük artış göstermiştir. Diğer taraftan ilim tahsil eden talebeler, tasavvufî bir atmosferde yetiştiklerinden mürid-talebe modeli yaygınlaşmıştır. Şark Medrese geleneği, Hâlidîlikle beraber pek çok köy ve beldede camilerde yaşatılmaya başlanmıştır. Diğer bir tabirle Hâlidîler, Şark Medreselerindeki tedrisatı camilere kaydırarak, camileri de canlandırmış, böylece merkez ve taşrada medreseli-cami modelinin çoğalmasına katkı sunmuşlardır. Mevlânâ Hâlid'in Divan'ı, medreselerde okunan diğer Farsça eserler arasında yerini alırken, Mevlânâ Hâlid'in Şam'da baş gösteren salgın sebebiyle müritlerine okumalarını tavsiye ettiği özel bir salavat duası, Hâlidî şeyhlerinin görev yaptıkları cami ve medreselerde namazlardan sonra okunmaya başlanmıştır. Bu çalışmanın amacı Hâlidîliğin Irak, İran ve Anadolu üçgeninde aktif tedrisat yürüten Şark Medreselerine tesirlerini irdelemektir. Hâlidîliğin yayılmasıyla beraber ilmî ve tasavvufî faaliyetlerin mezcedildiği Şark Medreselerinde kurumsal yapının zenginleştiği, tasavvufî içerikli eserlerle müfredatının genişlediği, müderrisliğe mürşid kimliğinin de eklenmesiyle öğretici kadronun statüsünün daha da güçlendiği, verilen tasavvufî eğitimle talebelerin eğitim öğretim programının çeşitlendiği ve bu medreselerde yetişen talebelerin toplumsal hayata daha donanımlı ve özgüvenli bireyler olarak katıldıkları sonucuna ulaşılmıştır.

Anahtar Kelimeler: Tasavvuf, Hâlidîlik, 19. Yüzyıl, Şark Medreseleri, Müderris-Sufi Modeli, Medreseli-Cami Modeli. 


\section{Abstract}

Naqshbandi is one of the most widespread Sufi orders in the Islamic World. The most active representative of this sufi order in the Middle East in the 19th century is Mawlana Khalid alBaghdadî. The Khâlidiyya branch, which was attributed to him, emerged as a Sufi revival movement that revitalized social life with its dynamic structure. One of the most prominent among the activities of the Khâlidiyya is the revival of the madrasahs. Considering that the Khâlidiyya first began to spread in the Shahrazor region of Iraq and among the Kurds living in Iran and Anatolia, the first institutions that it dealt with in the fields of science and education were the Eastern Madrasahs. These madrasahs are science centers established in a wide geography where the Kurdish population is concentrated, such as the Eastern and Southeastern Anatolia regions of Turkey, the northern regions of Iraq and Syria, and western regions of Iran. The Eastern Madrasahs operated as a continuation of the Baghdad Nizamiya Madrasah, which was for Shafiis and all its entire personnel, including teaching staff, were to be selected from Shafii Sect. They consisted mostly of simple structures built next to the mosques, apart from the well-established madrasahs such as Qubbahan Madrasah in İmadiya, Maweran Madrasah in Arbil, Biyara Madrasah in Havraman, Arwas Madrasa in Mokus (Bahçesaray) district of Van, Sheikh Ayn al-Malak Zaviya and Madrasah in Bulanık district of Muş. In the Eastern Madrasahs, where the education is mostly teacher-centered, the circulation of students among the madrasahs was high. In these science centers where students can stay as boarding students, the curriculum of the Baghdad Nizamiya Madrasa and Ottoman period madrasahs were followed. In the Eastern Madrasahs, some classical Works in Persian were preferred in the field of literature, as well as Arabic and religious sciences. In these Madrasahs, the mudarris taught the lessons in Kurdish, and the students discussed and read among themselves in Kurdish. On the one hand the Khâlidis made the existing madrasahs more active; on the other hand, they enabled the opening of many new madrasahs. This situation not only made significant contributions to the scientific and cultural life of the region, but also played a leading role in the formation of an intellectual layer. Managers, scholars, mudarrises, politicians, writers and poets that the society needed were trained in these centers of science, and they filled an important gap in these fields during their lifetime. As the Khâlidi lodges moved from the cities to the countryside, they gave way to modest cells adjacent to madrasahs or mosquest. With the spread of Khâlidiyya, the mudarris-sufi model has increased greatly among the scientists, since the mudarris, who took up education and training in the Eastern Madrasahs, also took on the task of guidance. On the other hand, the disciple-student model has become widespread since the students who received knowledge were brought up in a mystical atmosphere. The tradition of the Eastern Madrasahs is kept alive in mosques in many villages and towns with the Khâlidiyya. In other words, the Khâlidiyya moved the education in the Eastern Madrasahs to mosques and revived the mosques, thus contributing to the proliferation of the madrasah-mosque model in the central and provincial areas. While Mawlana Khalid's Diwan took its place among the other Persian Works read in madrasahs, a special salawat prayer that Mawlana Khalid recommended to his disciples to read due to the epidemic that broke out in Damascus was started to be read after prayers in mosques and madrasahs where Khâlidi sheikhs served. The aim of this study is to examine the effects of Khâlidiyya on the Eastern Madrasahs, which carry out active education in the triangle of Iraq, Iran and Anatolia. It was concluded that the institutional structure in the Eastern Madrasahs, where scientific and mystical activities were combined, flourished; the curriculum was expanded with works with mystical content; the status of the teaching staff was strengthened with the addition of the guide identity to the mudarrisship; the educational program of the students became more diverse with the provided Sufi education; and the students who grew up in these madrasahs participate in social life as more equipped and self-confident individuals.

Keywords: Sufism, Khâlidiyya, 19th Century, Eastern Madrasahs, Mudarris-Sufi Model, Madrasah-mosque Model. 


\section{Giriş}

Hicrî ikinci yüzyıldan sonraki birkaç asırda sûfîler, söylem ve yaşantılarıyla toplumsal hayatta irfanî bir bakış ve ihsanî bir tecrübenin temsilcileri olmuşlardır. İslam dünyasının farklı bölgelerinde her bir sûfî, İslam ahlak ve maneviyatı alanında şahsî düşünce ve tecrübeleriyle örnek bir kişiliğe dönüşmüş̧ür. Bu meyanda Hasan-1 Basrî’den (öl. 110/728) Rabiatü'l-Adeviyye'ye (öl. 185/801), Süleyman Dârânî’den (öl. 215/830) İbrahim Edhem'e (öl. 161/778), Hâris el-Muhasibî’ den (öl. 243/857) İmam Gazzâlî’ye (öl. 505/1111) kadar pek çok meşhur sûfîden bahsedilebilir. Medine-i Münevvere'den Bağdat'a, Misır'dan Horasan'a uzanan geniş bir coğrafyada adı geçen meşhur sûfîlerin düşünce, söylem ve tasavvufî birikimleri birer mektebe dönüşmüştür. ${ }^{1}$ Bundan sonraki süreçte tasavvufun kurumsallaşmaya başlamasıyla beraber ortaya çıkan tarikatlar ise faaliyetleriyle İslam toplumunda daha etkin ve yaygın bir hizmetin içine girmişlerdir. ${ }^{2}$

Tasavvuf temelli İslam dindarlığı, birkaç asırdan beri gerilemesine ve eski dinamizmini kaybetmesine rağmen, on dokuzuncu yüzyılda toplumsal hayatta rağbet edilen bir yaşam modeli olmuştur. Bu yüzyılda geleneksel tarikatların yanında İdrîsiyye, Senûsiyye, Mirganiyye ve Reşîdiyye gibi sslahat ve tecdid vizyonu ve tebliğ misyonuyla ortaya çıkan tasavvufî hareketler de faaliyetleriyle dikkat çekmişlerdir. ${ }^{3}$ Aynı dönemde Sünnî tasavvuf geleneğine bağlı kalarak Irak, İran ve Anadolu başta olmak üzere Ortadoğu, Asya ve Uzakdoğu'da iz bırakan ihyâcı bir hareket daha ortaya çıkmıştır. Şehrezorlu Mevlânâ Hâlid-i Bağdadî’ye (öl. 1242/1827) nisbet edilen bu hareket Hâlidîliktir. ${ }^{4}$ Nakşibendî-Müceddidî tasavvuf geleneğinin devamı olan Hâlidîlik, tarikatı şeriatle, tasavvufu ilimle ve tekkeyi medrese ile tevhid eden, ilmi önceleyen ve ulemâyı öne çıkaran yapısıyla ilmiye sınıfının yoğun ilgisine mazhar olmuştur. Genelde merkezden taşraya gidildikçe azalan ilmî ve tasavvufî faaliyetleri, tekke ve medrese faaliyetlerini camilere taşımak suretiyle taşraya da ulaştırmayı başarmıştır. Hâlidîliğin ciddi bir ivme ve dinamizm kazandırdığı medreselerin başında Kürtlerin yoğunlukta olduğu coğrafyada kurulan Şark Medreseleri gelmektedir. Hâlidîler, Şark Medreselerine yeni bir kimlik kazandırmış ve faaliyet alanlarını genişletmişlerdir. Bu çalışmada Hâlidîliğin Irak, İran ve Anadolu üçgeninde aktif tedrisat yürüten Şark Medreselerine etkileri irdelenecektir.

\footnotetext{
Ebu'l-'Alâ Afîfî, et-Tasavvuf es-sevretu'r-rûhiyye fi'l-İslâm (Beyrût: Dâru'ş-Şa'b, ts.), 80-95.

2 Mustafa Kara, Din Hayat Sanat Açısından Tekkeler ve Zaviyeler (İstanbul: Dergâh Yay., 1999), 52-212.

3 Kadir Özköse, Libya'da Tasavvufí Hayat (Senûsiyye Tarikatı) (Konya: Ensar Yay., 2008), 64-75.

4 Hamid Algar, Nakşibendîlik, çev. Cüneyd Köksal vd. (İstanbul: İnsan Yay., 2013), 109-114.
} 


\section{1. Şark Medreselerine Genel Bir Bakış}

İslamiyet'in Arapların yaşadığı coğrafyanın sınırlarını aşarak yayılmasıyla beraber bu dini kabul eden farklı milletler, Kur'an-1 Kerim ve Hadis-i şerifleri öğrenmek için Arapçaya yönelmişlerdir. Bu amaçla camilerde başlayan dinî eğitim öğretim bir süre sonra ilmî ve edebî muhitlerden saraylara kadar toplumsal hayatın hemen her alanında etkili olmuştur. ${ }^{5} \mathrm{Bu}$ hareketlilik zamanla medrese olarak adlandırılan köklü bir kurumunun ortaya çıkmasına zemin hazırlamıştır. İlk defa Karahanlılar döneminde Merv şehrinde açılan medreselerin, ${ }^{6}$ Büyük Selçuklu dönemi önemli devlet adamlarından Nizamülmülk'ün (öl. 485/1092) açtığ1 Nizamiye Medreseleriyle ${ }^{7}$ eğitim öğretimde doruğa çıktığını belirtmek gerekir. Nizamiye Medreselerinin başarısı, bu kurumsal yapının İslam dünyasının pek çok bölgesinde yayılmasına yol açmıştır. Selçuklu, Eyyûbî ve Osmanlı dönemlerinde açılan medreseler, ${ }^{8}$ bu misyonu sürdüren kurumlardır.

Türkiye'de Doğu ve Güneydoğu Anadolu bölgeleri, Irak ve Suriye'nin kuzey bölgeleri ile İran'ın batı bölgeleri gibi özellikle Kürt nüfusun yoğunluklu olduğu geniş bir coğrafyada kurulan Şark Medreseleri de ${ }^{9}$ Şafiî mezhebi ağırlıklı müfredatıyla Bağdat Nizamiye Medresesinin devamı niteliğinde faaliyet yürüten eğitim öğretim kurumlarıdır.10 $\mathrm{Bu}$ medreselerde okutulan ilmî eserler Arapça, edebî eserler ise çoğunlukla Farsçadır. Öğretim dili ise genellikle Kürtçe olmuştur. ${ }^{11} \mathrm{Bu}$ medreselerin fiziki yapısına baktığımızda İmadiye bölgesindeki Kubbehân Medresesi, Erbil'de bulunan Maveran Medresesi, Hevraman bölgesinde bulunan Biyâre Medresesi, Van'ın Müküs (Bahçesaray) ilçesinde bulunan Arvas

5 Ahmed Çelebi, İslam'da Ĕğtim Öğretim Tarihi, çev. Ali Yardım (İstanbul: Damla Yayınevi, 1983), 33-107; Hüseyin Uslu, Başlangıçtan Günümüze İslam Müesseseleri Tarihi (İstanbul: Gonca Yayınevi, 1985), 58-59.

6 Uslu, İslam Müesseseleri Tarihi, 61.

7 Çelebi, İslam'da Ĕ̆itim Öğretim Tarihi, 113-114.

8 Marshall G.S. Hodgson, İslam'ın Serüveni, çev. Alp Eker vd. (İstanbul: İz Yayıncılık, 1995), 2/48-54; Çelebi, İslam'da Eğitim Öğretim Tarihi, 113-130; Mahmut Dündar, Misır Eyyûbilerinde Eğitim ve Öğretim Faaliyetleri (İstanbul: Çıra Akademi Yayınları, 2017), 66-106; İsmail Hakkı Uzunçarşılı, Osmanlı Devleti'nin İlmiye Teşkilatı (Ankara: Türk Tarih Kurumu Yayınları, 2014), 3-46; Yusuf Halaçoğlu, Osmanlılarda Devlet Teşkilatı ve Sosyal Yapı (Ankara: Türk Tarih Kurumu Yayınları, 2014), 135-148.

9 M. Halil Çiçek, Şark Medreselerinin Serencâmı (İstanbul: Beyan Yayınları, 2009), 27.

10 Şark Medreseleri usul ve müfredat açısından Nizamiyenin devamı olmakla beraber donanım ve imkanlar açısından Nizamiye, Ezher, Fatih ve Süleymaniye Medreselerinin seviyesine ulaşamamıştır. Bk. Muhammed Sadık Hamidî, "Doğu ve Güneydoğu Medreselerinin Mahiyeti ve Ders Müfredatının Islah Önerisi”, Medrese Geleneği ve Modernleşme Sürecinde Medreseler Uluslararası Sempozyumu, ed. Fikret Gedikli (Muş: Muş Alparslan Üniversitesi Yay., 2013), 1/313. Kubbehân, Mâverân ve Biyâre Medreseleri oldukça aktif ve çok sayıda ilim ve tasavvuf erbabı yetiştirmekle beraber örneğin Biyâre Medresesi ancak "Küçük Ezher" benzetmesiyle takdir edilmiştir. Bk. Abdürrezzâk Abdurrahman Muhammed, Serbürdeki Havraman Serdaneki Tavîle (Tahran: Çaphâne-I Mahâret, 2005), 1311.

11 Çiçek, Şark Medreselerinin Serencâmı, 84. 
Medresesi, Muş'un Bulanık ilçesinde bulunan Şeyh Aynü'l-Melek Zaviye ve Medresesi gibi köklü medreselerin dışındakiler, cami bitişiğinde basit yapılardan oluşmuştur. ${ }^{12} \mathrm{Bu}$ nedenle bu tür medreseler için çoğu zaman "Hücre" tabiri kullanılmıştır. 30-40 metrekare arasında değişen daracık bir veya iki odadan oluşan bu hücre talebelerin hem dersliği hem yemekhanesi hem de yatakhanesi olarak kullanılmıştır. ${ }^{13}$

Şark Medreselerindeki hiyerarşi ve işleyişine baktığımızda sade, basit fakat kurumsal bir yapılanma karşımıza çıkmaktadır. Medresenin başında bulunan ve tedrisattan sorumlu olan şahsiyet "Mele/Molla" veya "Seyda" olarak isimlendirilmiştir. Bu isim halk arasında yaygınlaşmış ve kabul görmüştür. Medrese talebeleri genel olarak "faki" olarak isimlendirilirken, Molla Cami olarak bilinen Nureddin Abdurrahman Câmî’nin (öl. 898/1492) el-Fevâidü'z-ziyâiyye adlı Nahiv alanında telif ettiği eserini okuyanlara "tâlib" adı verilmiştir. Tâlibler diğer fakilerden farklı ve bir üst konumda olduklarından, yemek, temizlik ve diğer medrese hizmetlerinden muaf tutulmuşlardır. Medresede eğitim ve diğer hizmetlerin yürütülmesinde Seyda'nın yardımcısı konumunda olan talebeye ise "mîr" adı verilmiştir. ${ }^{14}$

Şark Medreselerinde şu dört hususun belirgin olarak öne çıktığını söyleyebiliriz.

1. Şark Medreselerinde tedrisat genellikle medrese değil, müderris merkezlidir.

2. Şark Medreseleri, müfredat olarak büyük oranda Bağdat Nizamiye Medresesi ile kısmen Osmanlı dönemi medreselerinin devamı niteliğindedir.

3. Medreseler arası talebe sirkülasyonu fazladır. Talebeler herhangi bir medreseye bağlı kalmaksızın belli aralıklarla birden çok müderristen ders okuma imkanına sahiptirler.

4. Şark Medreselerinde farklı milletlerden öğrenciler de bulunmakla beraber genellikle ders anlatım ve konuların müzakere dili Kürtçe olmuştur. ${ }^{15}$

Şark Medreselerinin belki de en yaygın ve en mümeyyiz vasıflarından biri tedrisatın medrese değil, müderris merkezli oluşudur. Bu sayede ilim ve tedrisat sadece şehirlerle sınırlı kalmamış pek çok kasaba, belde ve köye kadar yayılmıştır. Böylece dinî eğitimle beraber genelde şehirlerde yoğunlaşan entelektüel çevrenin sınırları taşraya kadar genişletilmiştir.

Osmanlı döneminde bu yapısı ve özellikleriyle faaliyet yürüten Şark Medreseleri, Cumhuriyet döneminde benimsenen yeni eğitim öğretim usul ve uygulamaları ile misyonunu yerine getiremez hale gelmiştir. Türkiye'de faaliyet alanı ve imkânı kısıtlanan Şark

12 Sabahattin Bala, Yitik Bir Miras Şark Medreseleri (İstanbul: Hiperyayın, 2019), 113.

13 Sadreddin Öztoprak, Şark Medreselerinde Bir Ömür (İstanbul: Beyan Yay., 2003), 42.

14 Çiçek, Şark Medreselerinin Serencâmı, 40-45.

15 Çiçek, Şark Medreselerinin Serencâmı, 84-85. 
Medreselerinin müderrisleri, Doğu ve Güneydoğu'daki bazı belde ve köylerde eğitim öğretim için çok da uygun olmayan mekanlarda bu geleneği yaşatmak için bir mücadelenin içine girmişlerdir. Aynı süreçte Irak, Suriye ve İran'da bulunan Şark Medreseleri ise herhangi bir yasaklamaya maruz kalmadan faaliyetlerine devam etmişlerdir. Türkiye'de Şark Medreselerinin bu sıkıntılı durumu 1950'li yıllara kadar devam etmiştir. Çok partili döneme geçiş ve Demokrat Partinin iktidara gelişiyle beraber Şark Medrese geleneği mensupları faaliyetlerini taşradaki köylerden şehirlere kaydırmaya başlamışlardır. Şark ulemasının yetiştiği bu ilim merkezlerinin günümüze kadar devam etmesinde en önemli faktörlerden biri, halk nezdinde elde ettikleri saygın konumdur. Halk dinî konularda medrese mezunlarını daha güvenilir bulmakta, toplumsal ve kültürel anlamda bu şahsiyetleri kendine daha yakın görmektedir. Resmî kurumlarda din eğitimi almış şahsiyetler ise, medrese tahsili görmüş meslektaşlarına göre toplumsal kabule daha az mazhar olarak görevlerini sürdürmek zorunda kalmışlardır. ${ }^{16}$ Bununla beraber son yıllarda hem Şark Medreselerinde yetişmiş hem de İmamHatip Liseleri ve İlahiyat Fakültelerinde din eğitimi almak suretiyle toplumsal alanda görev yapanların sayısı artmaktadır. İlim icazetli ve diplomalı bu şahsiyetlerin bir taraftan müderris kimlikleriyle medreselerde, diğer taraftan müftü, vaiz, imam-hatip ve müezzin kadrolariyla Diyanet İşleri Başkanlığı bünyesinde, akademisyen kimlikleriyle de ilahiyat fakültelerinde görev almaları, kadim medrese geleneği ile modern din eğitim ve öğretim anlayışının ortak bir zeminde ve birbirine katkı sunabilecek imkân ve şartların oluşturulması hususunda olumlu bazı gelişmelere kapı aralayacağı söylenebilir.

\section{Hâlidî Tasavvuf Geleneğinde İlim ve Medrese}

Hâris el-Muhasibî’den (öl. 243/857) Ebû Hâmid el-Gazzâlı̂’ye (öl. 505/1111), Abdülkadir Geylânî'den (öl. 561/1166) Muhammed Bahaüddin Nakşibend'e (öl. 791/1389) kadar bütün tanınmış sûfîler, Arapça ve dinî ilimlerin tahsiline büyük önem vermişlerdir. Şeriat ve tarikat dengesine dikkat çeken sûfîler, şeriatın tarikatın temelini ve özünü oluşturduğu hususunu eserlerinde vurgulamışlardır. Nakşibendiyye tarikatında Hâceganiyye döneminden Hâlidiyye'ye kadar geçen süreçte şeriata yapılan vurgu giderek artmış, ilmi, alimi ve medreseyi önceleyen düşünce, uygulama sahasında çok güçlü bir zemine oturmuştur.

16 Deniz Aşkın, “Geleneğin Savunucusu: Türkiye'de Geleneksel Şark Medreseleri ve Müderrislerin (Seydaların) Modern Din Eğitimine Eleştirileri", Anemon Muş Alparslan Üniversitesi Sosyal Bilimler Dergisi (2010 8/1), 13. 
Öyle ki bu konu Mevlânâ Hâlid-i Bağdadî (öl. 1242/1827) ile beraber Nakşibendî-Hâlidî tasavvuf geleneğiyle özdeşleşen bir pratiğe dönüşmüştür.

Hâlidî tasavvuf geleneği, kurucusu Mevlânâ Hâlid-i Bağdâdî’nin düşünce ve uygulamaları çerçevesinde şekillenmiş ve bu gelenek takipçileri tarafından günümüze kadar devam ettirilmiştir. Hâlidîlikte şeriat ve tarikat dengesine son derece riayet edilirken, eğitim hususunda da ilim ve medreseye çok ciddi bir ehemmiyet verilmiştir. İlim ve medrese ayağ şeriatı, seyr ü sülûkla devam ettirilen manevî ve ahlakî eğitim de tarikat boyutunu temsil etmiştir. Doğrusu Hâlidîlikte medrese ve tekke faaliyetleri tevhid edildiğinden ve başından itibaren talebe olarak Hâlidî şeyhlerinin rahle-i tedrislerine girenler aynı zamanda irşad halkasına da dahil olduğundan, ilim ve tedrisat seyr ü sülûkün başlangıcı olmuş, bunu ruhî ve ahlakî eğitim süreci takip etmiştir. Iraklı tarihçi Abbas Azzâvî (öl. 1971), Hâlidîlerin ilim ve medreseyi önceleyen tavırları, bidat ve aşırılıktan uzak, makbul ve ma'kûl bir yaşam tarzına sahip olmalarını övmekte ve bu durumun Hâlidî tasavvuf geleneğinin başarısındaki başlıca husus olduğunu vurgulamaktadır. ${ }^{17}$

19. yüzyıldan itibaren Ortadoğu'nun pek çok büyük ilim kültür merkezinde faaliyet yürüten Hâlidî mensupları arasında dönemin tanınmış büyük alim ve şairlerinin bulunması ve bunların bizzat ilim ve tedrisatla uğraşmaları, ilim ve medresenin Hâlidîlikte bir geleneğe dönüştüğünün en büyük göstergesidir. Şöhreti Irak sınırlarını aşan Allâme Molla Yahya elMizûrî (öl. 1252/1836), Mevlânâ Hâlid'in ilim ve tedrisatla uğraşması için görevlendirdiği ve Ruhu'l-me'ânî adlı tefsiriyle tanınan Bağdatlı halifesi Ebü's-Senâ Şihâbüddin el-Âlûsî (öl.1270/1854), ${ }^{18}$ Bağdat'ta ilmiye sınıfı arasında saygın bir konuma sahip Haydarî ailesi mensubu Şeyh Ubeydullah Haydarî (öl. ?), Süleymaniye şehrinin aktif alim ve mutasavvıflarından Şeyh Osman Siracüddin et-Tavîlî (öl. 1283/1866), Şam'ın tanınmış Hanefî ulemasından, Reddü'l-muhtâr adlı eserin sahibi ve Mevlânâ Hâlid'in hadis icâzeti verdiğ $\mathrm{i}^{19}$ ilim çevrelerinde kısaca İbn Abidin diye tanınan Muhammed Emîn el-'Abidîn (öl. 1252/1836), ilim ve tasavvuf alanında Şam'ın saygın ailelerinden Hânîlere mensup Muhammed b. Abdullah el-Hânî (öl. 1279/1862), Suriye'nin kuzeyinde saygın bir konumda olan Şeyh Ahmed Haznevî (öl. 1950), Anadolu'dan Şam’a göç eden Molla Ramazan el-Bûtî (öl. 1410/1990), İran' da Durûd

Abbas Azzâvî, “Hulefâu Mevlânâ Hâlid”, Mecelletü'l-mecma'i'l-'ilmiyyi'l-Kürdî (1974/2), 182.

18 Âlûsî'nin hayatı ve eserleri için bk. Azzâvî, Zikrâ Ebi's-Senâ'l-Âlûsî (Bağdat: Şirketu't-Ticâreve't-Tibâ'a, 1958), 492; Muhammed Behcet el-Eserî, A'lâmu'l-Irâk (Beyrût: ed-Dâru'l-Arabiyye Li'l-Mevsû'ât, 2002), 25-35.

19 İbn Abidîn'in Mevlânâ Hâlid'den aldığı hadis icâzeti için bk. Abdülkerim Müderris, Yâd-ı Merdân (Hevler: Çaphâne-I Ârâs, 2011), 1/340-341. 
Tekkesini kuran Şeyh Alaaddin Biyârî (öl. 1953), Kafkasya bölgesinde Şeyh Şamil'in de içinde yer aldığı pek çok alim ve komutanın yetiştiği Yukarı Yerağlı Medresesini kuran Şeyh Muhammed Yerağî (öl. 1265/1848) ve yakın dostu Has Muhammed Şirvanî (öl. 1260/1844), Kazan bölgesinin aktif alimlerinden Şeyh Zeynullah Resulev (öl. 1917), Türkiye'de Nehri Medresesini Hâlidî tasavvuf geleneğiyle buluşturan Seyyid Taha Hakkarî (öl. 1269/1853), Gayda Dergahını kuran Seyyid Sibğatullah Arvasî (öl. 1287/1870), Küfrevî Tekkesinin pîri Şeyh Muhammed Küfrevî (öl. 1315/1898), Norşin Medresesini kuran Şeyh Abdurrahman-1 Tâğ̂̂ (öl. 1304/1886), Şeyh Hâlid el-Cezerî (öl. 1255/1839), Cizre ve Serdahl tekkelerinde ilim ve irşad faaliyetleri yürüten Şeyh Seyda el-Cezerî (öl. 1968), Bingöl ve çevresindeki faaliyetleriyle bilinen Şeyh Ali Sebtî (öl. 1287/1871), ${ }^{20}$ İstanbul'da Gümüşhanevî Dergahını kuran ve hadis sahasında Râmûzu'l-ehâdîs adlı eserin müellifi² ${ }^{21}$ Ahmed Ziyaüddin Gümüşhanevî (öl. 1311/1893), bu dergahin müntesiplerinden İstanbul, Ankara ve Konya'da geleneksel medrese eğitimi ile ilahiyat fakültesi eğitim programını mezcederek fıkıh ve hadis ağırlıklı ilim merkezleri açan Şeyh Mahmud Esad Coşan (öl. 2001)22 bu şahsiyetlerden sadece birkaçıdır. Yine Arapça, Farsça, Kürtçe ve Türkçe yazdıkları şiirler ve tertip ettikleri tasavvufî Divanlarla tasavvuf edebiyatı alanına katkı sunan pek çok Hâlidî mensubundan bahsedilebilir. Büyük çoğunluğu Irak, Anadolu ve İran'da yaşamış olan bu Hâlidî şair ve edebiyatçılarından bazıları şunlardır: Muhammed Havramî (öl. 1265/1848), Ma'dûm mahlaslı Abdurrahim Mevlevî (öl. 1300/1883), Ubeydullah-1 Nehrî (öl. 1300/1883), Muhammed Hazîn Firsafî (öl. 1308/1890), üç ciltlik Farsça Mesnevî şerhi bulunan Hamid b. Ali el-Bîsârânî (öl. 1312/1894), Mahvî mahlaslı Muhammed Osman (öl. 1326/1908), Selim Senendecî (öl. 1326/1908), Hâkî mahlaslı Muhammed Can Aktepî (öl. 1327/1909), R̂̂hî mahlaslı ve Ravdu'n-na'îm adlı eserin ${ }^{23}$ müellifi Abdurrahman Aktepî (öl. 1328/1910), Kerbelâî mahlaslı Muhammed Aktepî (öl. 1358/1939), Halife Yusuf (öl. 1387/1968), Seyyid Ali Findıkî (öl. 1387/1968), Muhammed Said Cezerî (öl. 1388/1968), Şeyh Müşerref Pervârî (öl. 2005). ${ }^{24}$

20 M. Şirin Ayiş, “Bingöl Hâlidî Geleneğinin Medrese Boyutu”, Bingöl Üniversitesi İlahiyat Fakültesi Dergisi 5/10 (2017), 73-75.

21 İrfan Gündüz, Gümüşhanevî Ahmed Ziyâüddin Hayatı- Eserleri-Tarîkat Anlayışı ve Hâlidiyye Tarîkatı (İstanbul: Seha Neşriyat, 1984), 61.

22 Selim Özer, “Modernleşme Sürecinde Geleneksel Dinî Gruplar: “İskenderpaşa Cemaati” Örneği” (Doktora Tezi), Bursa Uludă̆ Üniversitesi Sosyal Bilimler Enstitüsü (Bursa: 2018), 102.

23 Abdürrahman el-Aktepî, Ravdu'n-Na'îm (Diyarbakır: Mektebetu Seyda, 2010).

24 Hamdi Abdülmecid es-Selefî, Tahsin İbrahim ed-Dûskî, Mu'cemu'ş-şu'arâi'l-Kurd (Duhok: Dâru Spîrez, 2002), $158 \mathrm{vd}$ 
Hâlidîlerin Ortadoğu'nun pek çok bölgesinde açtıkları medreseler, o bölgelerin ilim ve kültür hayatına önemli katkılar sunduğu gibi entelektüel bir tabakanın oluşmasında da öncü rol oynamıştır. Bu ilim merkezlerinde toplumun ihtiyacı olan yönetici, âlim, müderris, siyasetçi, yazar ve şairler yetişmiş ve yaşadıkları dönem bu alanlarda önemli bir açığı kapatmıştır. Bu meyanda Irak'ta Biyâre Medresesi, İran'da Durûd Tekkesi, Suriye'de Muradiye Tekkesi Hicaz bölgesinde Cebel-i Kubeys Tekkesi, Dağıstan'da Yukarı Yerağlı Medresesi, Malezya'da Lengkat ve Johore Halidî Pasantrenleri, Anadolu' da Norşin, Sami Paşa ve Gümüşhânevî medrese ve dergâhları yukarıda söz konusu edilen misyonu yürüten Hâlidî medrese ve tekkeleridir. ${ }^{25}$

\section{Hâlidîliğin Şark Medreselerine Tesirleri}

\subsection{Kurumsal Yapısina Tesirleri}

Mevlânâ Hâlid'in kendisi oldukça aktif, girişken, zeki ve cesur bir müderris olarak tanınmıştır. Yetiştiği Şehrezur'un medreseler açısından zengin bir bölge oluşu ve müderrislerin idareci ve halk nezdindeki saygınlıklarının farkında olarak bu köklü kurumun daha da güçlendirilmesi gerektiği fikri onda iyice olgunlaşmıştır. Bu sebeple Şark medreselerinin yanı başında tekke açmak yerine, tekkelerle hedeflenen iş ve işlemleri de medrese ortamına taşımak suretiyle medreseleri büyütmek ve güçlendirmek yolunu tercih etmiş ve büyük oranda başarılı olmuştur.

Tasavvufun kurumsallaşmaya başladığı Miladî on ikinci yüzyıldan beri medreselerden ayrı bir mekânda faaliyet yürüten tekkeleri medrese çatısı altına alan Mevlânâ Hâlid, bu sayede öncelikle iki kadim kurumun fiziki birlikteliğini sağlamıştır. Bu fiziki birliktelik iki saygın kurumu birbirine yaklaştırmakla kalmamış zamanla program ve faaliyetlerinin ortaklaşmasının yolunu açmıştır. Medreseler, tekke faaliyetleriyle zengin bir rûhî ve manevî atmosfere kavuşurken, tekkeler de medreselerin entelektüel ikliminde kendilerini topluma ifade etme açısından daha sağlam ve güçlü bir zemine kavuşmuştur.

“Mevlânâ Hâlid'in tekke ve medreseyi birleştirme projesi, medrese eğitimi almak isteyenlerle tasavvufî eğitim almak isteyen kesimleri aynı ortamlarda ve çoğu zaman tek çatı altında bir araya getirmiştir. Bu sayede sadece ilim ve tedrisatla uğraşan ve tasavvufa uzak duran kesimler, zorunlu olarak cami ve medreselerde aynı saflarda namaz kılıp aynı

25 Abdulcebbar Kavak, Mevlânâ Hâlid-i Nakşibendî ve Hâlidîlik (İstanbul: Nizamiye Akademi Yay., 2016), 403-404, 417-418. 
mürşidden ders almaya başlamışlardır. Mekânlardaki bu yakınlık zamanla gönüllerin de yaklaşmasına ve medrese ehliyle tekke ehli arasında zaman zaman oluşan buzların erimesine neden olmuştur. Bu yönüyle bakıldığında Hâlidî tasavvuf geleneği, İslâm toplumundaki iki önemli kesimi aynı potada eritebilen ve bu sayede toplumsal birlik ve beraberliğe de hizmet eden bir özellik arz etmektedir." 26

Mevlânâ Hâlid'in temelini attığı Hâlidî tasavvuf geleneğinde önce tekke faaliyetleri medreseye taşınmıştır. Böylece tasavvufî faaliyetler ilmî faaliyetlerle iç içe ve uyumlu bir hale getirilmiştir. Bu merhaleden sonra özellikle Bağdat ve Şam'da bulunduğu dönemlerde Mevlânâ Hâlid'in yönlendirmesiyle her iki kurumsal yapının faaliyetleri camilerde tevhid edilmiştir. Cami, medrese ve tekke üçlüsü aynı çatı altında temel misyonlarını kaybetmeden bir araya getirilmiştir. Bu sayede bir model olarak medrese-camiler ortaya çıkmış ve yaygınlaşmıştır. Doğrusu bu durum Mescid-i Nebevî’nin Ashab-1 Suffeli halini akla getirmektedir. Halidîler ilmî ve tasavvufî faaliyetlerini camilere taşımak suretiyle camileri, Hz. Peygamber dönemindeki aktif misyonuan kavuşturma hususunda önemli bir adım atmışlardır. Diğer taraftan bu model ile hem iktisadî açıdan hem de mekân, zaman ve insan açısından büyük bir tasarrufta bulunmuşlardır.

\subsection{Eğitim ve Öğretimin Temel Unsurlarına Tesirleri}

\subsubsection{Ders Sistemi ve Müfredata Tesirleri}

Şark Medreselerinin ders sisteminde sıralı kitapların okunması, derslerin müzâkere ve mütâla'ası genel bir teamül olarak devam etmiştir. ${ }^{27}$ Ders müfredatını oluştururken de Bağdat Nizamiye Medresesinin Şâfiî mezhebi ağırlıklı müfredatını temel aldıkları, süreç içinde dinî ilimler alanında okutulan bazı eserlerle edebiyat alanında Farsça bazı klasiklerin müfredata dahil edildiğini söyleyebiliriz. Fıkıhta Hanefî mezhebine ait bazı eserler okutulmakla beraber Şafii fıkhı ağırlıklı müfredat ve müderrislerin bulunduğu Bağdat Nizamiye Medresesinin örnek alındığı ve bu durumun Şark Medreselerinde tevarüsen devam ettirildiği görülmektedir. Bilindiği üzere Bağdat Nizamiye Medresesinin Vakfiyesinde "medresenin Şafiîler için yaptırıldığı, görevlendirilecek müderristen ferraş ve kapıcılarına kadar hepsinin Şafiî olması gerektiği vurgulanmıştır."28 Şark Medreselerinin bulunduğu coğrafyada halkın

26 Kavak, Mevlânâ Hâlid-i Nakşibendî, 203.

27 Hamidî, "Doğu ve Güneydoğu Medreselerinin Mahiyeti”, 1/ 317-318.

28 Abdülkerim Özaydın, "Nizâmiye Medresesi", TDV İslam Ansiklopedisi (İstanbul: TDV Yay., 2007), $33 / 189$. 
çoğunlukla Şafiî mezhebine mensup olmaları da bu durumu olağan hale getiren hususlardan biridir.

Şark Medreseleri Şâfiî mezhebine ait eserler dışında Osmanlı dönemindeki diğer medreselerle hemen hemen aynı müfredatı takip etmişlerdir. Buna göre "Dil ilimleri, Felfefe ilimleri, Şer'î ilimler, Münâzara ve Hat" medrese müfredatının ilim iskeletini oluşturmuştur. Cumhuriyet döneminde ise daha önce okutulan bazı usul dersleri ile Astronomi, Felsefe ve Matematik derslerinin tedrisatı terk edilmiştir. ${ }^{29}$ Talebelere okutulan eserlerde ise genel olarak şöyle bir sıra takip edilmiştir. Arapça elifba öğretilerek Kur'an-1 Kerim okutulduktan sonra özellikle Kürtçenin Kurmancî lehçesinin konuşulduğu bölgelerdeki medreselerde Ahmed-i Hânî’nin (öl. 1119/1707) Nûbihar adlı Arapça-Kürtçe sözlüğü, ardından Molla Halil es-Siirdî'nin (öl. 1258/1843) akaid ve ahlak içerikli Nehcü'l-enâm adlı Kürtçe eseri okutulmuştur. Bu arada Molla Hüseyin Bâteyî'nin (öl. 1163/1750) Kürtçe Mevlid'i de yaygın olarak okutulan eserler arasında yer almıştır. Talebeler bunun ardından Molla Ali Teremahî’nin (öl. 1065/1655) Sarf alanında kaleme aldığı Kürtçe Tasrîf kitabını okumuşlardır. Bu alandaki müellifi belli olmayan Bina kitabı ve İzzüddîn b. İbrâhîm ez-Zencanî'nin (öl. 660/1262) İzzî adlı eseri okunduktan sonra Nahiv alanında Abdülkâhir b. Abdurrahman elCürcânî'nin (öl. 471/1078) el-Avâmil'i, Zurûf ve Molla Yunus Erkatinî'nin Terkîb adlı Kürtçe eseri takip etmiştir. Sa'd-i Teftazanî’ye (öl. 793/1391) nispet edilen Sadullah-ı Sağî̀ adıyla bilinen eser okunduktan sonra Şafiî fıkhını kısa ve sade bir şekilde ele alan Ebû Şücâ' elİsfahânî'nin (öl. 500/1107) daha çok Gâyetü'l-ihtisâr adıyla bilinen et-Takrîb adlı eseri okunmuştur. Bundan sonra Nahiv ilmine dair telif edilen Muhammed b. Abdurrahman elMilanî'nin Şerhu'l-Muğgĥ, Mes'ud b. Ömer et-Teftazanî'nin (öl. 792/1390) Sa'dînî, Ebü's-Senâ Ahmed b. Muhhammed'in Hellu'l-Me'âkid, Sa'dullah Berdeî'nin Sa'dullah-i Kebîr (Sadullah Gevre), Mustafa Adalı'nın Netâyicü̈l-efkâr adlı bir dizi kitap okunduktan sonra Molla Abdurrahman Câmî'nin (öl. 898/1492) el-Fevâidü̈d-diyâiyye yahut İmam Suyûtî'nin (öl. 911/1505) telifi olan el-Behçetü'l-marziyye fî şerhi'l-Elfiyye adlı eserlerinden biri okutulmuştur. Bu merhalede Mantık alanında Mufaddal b. Amr el-Ebherî’nin (öl. 700/1300) İsagoji adlı mantık risalesine, Mahmud b. Hafız Hasan'ın (öl. 1222/1807) yaptığı şerh olan Muğni't-tullâb ve yine aynı esere Hüsamüddin Hasan el-Katî'nin (öl. 760/1359) yaptığı ve Hiissemkatî diye bilinen eser okunmuş bunu diğer bazı mantık şerhleri takip etmiştir. Daha sonra dinî ilimler

29 Çiçek, Şark Medreselerinin Serencâmı, 46. 
alanında fıkıhta İbn Hacer el-Heytemî'nin (öl. 974/1566) Tuhfetü'l-muhtâc adlı eseri, fıkıh usulünde Tâcüddin Abdülvehhâb b. Ali es-Sübkî'nin (öl. 771/1368) Cem'u'l-cevâmi' adlı eseri, hadiste Ebû Zekeriyya Yahya en-Nevevî́nin (öl. 676/1277) Riyâzü's-sâlihîn, Mansur Ali Nâsıf'ın (öl. 1341/1928) Tâcu'l-câmi'i'l-usûl fì ehâdîsi'r-Resûl adlı eserler, tefsirde başlangıç için Celalüddin Abdurrahman es-Suyûtî (öl. 911/1505) ile Celalüddin Muhammed el-Mahallî (öl. 864/1459) nin eseri olan Tefsîru'l-Celâleyn, Nesefî́nin (öl. 710/1310) Medârikü't-tenzîl ve hadâiku't-te'vîl, Kadı Beyzâvî'nin Envâru't-tenzîl ve esrâru't-te'vîl adlı eserleri ile akaid alanında Sa'düddin Mesud b. Ömer et-Teftazânî’nin (öl. 792 ), Ömer b. Muhammed en-Nesefî’nin (öl. 537/1142) Akâid adlı eserine yaptığı şerh olan Şerhu'l-Akâid adlı kitap okutulmuştur. ${ }^{30}$

Hâlidîler, Şark Medreselerinin ders sistemine müdahale etmedikleri gibi ders müfredatını da aynen devam ettirmişlerdir. Yalnız medrese talebelerinin tasavvufî alanda bilgi sahibi olmaları için bazı eserlerin sohbet halkalarında okutulması ve tasavvuf edebiyatı alanında yaygın olan bazı Farsça eserlerin seçmeli ders statüsünde okutulması yoluna gitmişlerdir. Bütün Şark Medreseleri için söz konusu olmamakla beraber Bitlis'te Norşin Medresesi gibi bazı merkezi tekkelerle Ağrı'da Kasor Medresesi gibi nispeten daha küçük medreselerde Mevlânâ Halid-i Bağdadî'nin Divan'ı okutulmuştur. Bu Divan'ı seçtiği özel talebelere okutan müderrislerden biri Bitlis'te Molla Sadreddin Yüksel ile Ağrı'da Molla Muhammed Kasorî́'dir.

\subsection{2. Öğretici Kadroya Tesirleri}

Şark Medreselerinde yönetim ve öğretici kadro aynı kişilerden oluşmuştur. Medresenin yönetim ve tedrisatından sorumlu olarak en üst mertebede yer alan kişi Seyda olarak isimlendirilen baş müderristir. Medresenin talebe sayısına göre bu Seyda'ya yardımcı olan müderrisler ve talebeler arasından seçilen ve "mîr" adı verilen bir sorumlu bulunmuştur. ${ }^{31}$ Hâlidîliğin yayılmasıyla beraber müderrisler aynı zamanda tasavvufî bir paye olan şeyhlik kimliğine de sahip olmuşlardır. Böylece Şark Medreselerinde müderris-sûfi modeli yaygınlaşmıştır. İlim tahsilinin son merhalesinde olan yahut ilim icazeti alan ve muid vasfıyla tedrisata yardımcı olan genç müderrisler de şeyhlerinden ilim ve irşad izni aldıktan sonra, halifeleri olarak medresenin eğitim-öğretim yüküne omuz vermişlerdir.

30 Çiçek, Şark Medreselerinin Serencâmı, 46-77; Hamidî, “Doğu ve Güneydoğu Medreselerinin Mahiyeti”, 1/319-323; Tahsin İbrahim Dûskî, Feqî î Melâ û Medrese (Duhok: Weşânên Êkitiya Zanayên Âyinî İslamî, 2012), 18-25; Şaban Argun, İrşad Sami Yuca, “Muş Bulanık Mollakent/Mellekend Medresesinden Bir Âlim Portresi: Şeyh İhsan-1 Mellekendî́nin Hayatı ve İcâzetnâmesi”, e-Şarkiyat İlmi Araştırmalar Dergisi 11/1 (2019), 157-159

31 Hamidî, “Doğu ve Güneydoğu Medreselerinin Mahiyeti”, 1/315; Bala, Şark Medreseleri, 117. 
Hâlidîler, diğer tarikat mensuplarından farklı olarak kendilerine has bir kıyafet ihdas etmemiş bunun yerine ilmiye sınıfının kıyafeti olan sarık ve cübbeyi tercih etmişlerdir. Bu durum medrese ortamında hem müderris hem de mürşid payeleriyle görev yapan Hâlidî mensuplarının işini kolaylaştırmıştır. Böylece görsel açıdan çok büyük bir farklılık olmadan tasavvufî ortam, medresenin ilmî ortamıyla buluşmuştur.

\subsubsection{Talebelere Tesirleri}

Şark medreselerinde talebeler eğitim düzeylerine göre isimlendirilmişlerdir. Buna göre yeni başlayanlar yani mübtediler "faki", Molla Câmî’nin (öl. 898/1492) el-Fevâidü'd-diyâiyye yahut İmam Suyûtî́nin (öl. 911/1505) el-Behçetü'l-marziyye adlı eserini okumaya başlayanlara "tâlib" denmiştir.32

Medreselere on yaşından itibaren talebe kabul edildiği kaydedilir. Medrese okuyan talebelerin yaşları ve yüzdeleri için şu tespitler yapılmıştır: ${ }^{33}$

10-15 Yaş arasındaki talebelerin oranı \% 26,5

16-20 Yaş arasındaki talebelerin oranı \% 67,3

21-25 Yaş arasındaki talebelerin oranı \% 5,6

26 Yaş ve üstü talebelerin oranı ise $\% 0,6$

Hâlidîliğin yayılmasıyla beraber medreseye başlayan talebeler günlük medrese derslerinin yanında tasavvufî sohbetlere de katılmaya başlamışlardır. Hâlidî medreselerindeki talebeler çift yönlü yani mezcedilmiş ilmî ve tasavvufî ortamda yetiştiklerinden her talebe aynı zamanda bir mürit olarak ders ve eğitim almıştır. Bu şekilde Hâlidî şeyhlerinin müderrislik yaptığı Şark medreselerinde mürit-talebeler modeli ortaya çıkmıştır. Talebelerin büyük çoğunluğu bu mürit-talebe modeline uygun bir şekilde yetişip ilim icazeti alırken, irşad için kabiliyetli olan talebelere, ilim icazetinin yanında çok uzun süre devam etmeyen bir tasavvufî eğitime tabi tutulduktan sonra hilafet verilmiştir.

\subsubsection{Medresedeki Günlük İbadet ve Duâlara Tesirleri}

Hâlidîlerin Şark Medreselerindeki ibadet ve dualara en büyük katkısı, fıkh-1 zâhir'e fıkh-ı batını da eklemek suretiyle ibadet ve duaların daha bilinçli ve kalbî yapılmasını sağlamalarıdır. Said-i Nursî, Norşin Medresesinde bulunduğu yıllar orada müderrislik yapan

32 Çiçek, Şark Medreselerinin Serencâmı, 40-45; Şakir Epözdemir, Medreseyên Kurdıstanê, (İstanbul: Nûbihar Yay., 2015), 33.

33 Bala, Şark Medreseleri, 150. 
Hâlidî şeyhlerinin ibadet ve günlük yaşamlarından çok etkilenmiş ve onları "fukara klyafetinde melikler, padişahlar ve insan elbisesinde melâikeler" olarak nitelemiştir. ${ }^{34}$

Mevlânâ Hâlid'in beş vakit namazın ardından okunmasını istediği iki salavâtı şerîfe duâsı Hâlidî medreselerinde namazlardan sonra okunmuştur. Bu dualar günümüzde de pek çok cami ve medresede hala okunmağa devam etmektedir. Bunlardan birincisi farz namazın ardından on kere okunan "Lâ ilâhe illallah" a onuncu seferde "Muhammedun Resûlullah" eklenip, Hz. Peygamber'in, âlinin ve meşâyihin ruhlarına elfatiha denir ve şu duâ okunur.

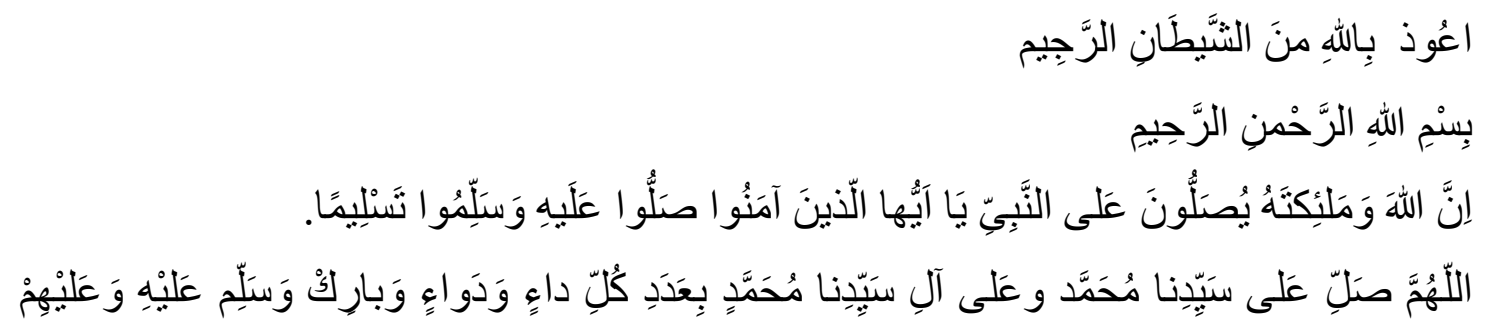

Bu dua üç kere tekrar edilir. Üçüncüde (كَثِيرً (كَ) iki defa söylenir ve dua şöyle tamamlanır:

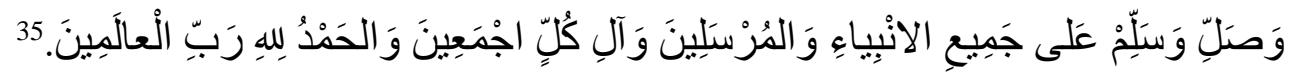

\subsubsection{Medresenin Toplumsal Etkilerine Tesiri}

Medreseler, Arapça ve dinî ilimlerin yanında matematik, astronomi, fizik, kimya gibi pek çok ilmin öğretildiği en temel İslamî kurumlardan biri olarak yüzyıllarca hizmet vermiştir. $\mathrm{Bu}$ kurumların en önemli misyonlarından biri de İslam kültür ve medeniyetine ait teraküm eden mirasın yazılı ve sözlü olarak nesilden nesile aktarılmasını sağlamaktır. Bu kurumlarda yetişen ilim talebeleri, devraldıkları mirası toplumsal hayatta üstlendikleri müderrislik, imamhatiplik, vaiz ve müftülük gibi görevlerle en iyi ve en geniş bir kesime ulaştırmak için çabalamışlardır. Başından beri ilmiye sınıfı mensuplarının yetiştiği bu kurumlar saygın bir yere sahip olmuş hem devlet ricali hem de halkın ilgi ve takdirine mazhar olmuştur. Şark Medreseleri özelinde konuyu ele aldığımızda toplumsal hayata tesirleri açısında pek çok medreseden bahsedilebilir. Fakat bazıları vardır ki buralarda yetişen şahsiyetler ilim, kültür, sanat ve edebiyatta yaşadıkları çağa damgasını vurmuş ve isimleri günümüze kadar devam

34 Said Nursî, Mesnevî-i Nûriye, çev. Abdülmecid Nursî, (İstanbul: Sözler Yay., 1977), 239-240

35 İbrahim Çokreşî, Kitâbü'l-İşârât (Yazma nüsha fotokopisi), 159. 
etmiştir. Biyâre Medresesi, ${ }^{36}$ Arvas Medresesi, ${ }^{37}$ Şeyh Aynü'l-Melek Zaviye ve Medresesi, ${ }^{38}$

Maveran Medresesi, ${ }^{39}$ Medresa Sor (Kırmızı Medrese), ${ }^{40}$ Kubbehân Medresesi, ${ }^{41}$ Nehri

Medresesi $^{42}$ ve Norşin Medresesi ${ }^{43}$ bunlardan bazılarıdır.

36 Biyâre Medresesi sekiz yüz yıllık geçmişiyle Kuzey Irak bölgesinin en kadim medreselerinden biridir. Günümüzde Halepçe şehrinin idari sınırları içinde yer almaktadır. Mevlânâ Hâlid-I Bağdadî’nin (öl. 1242/1827) de bir dönem ders aldığı bu medrese, on dokuzuncu yüzyılın ilk çeyreğinden itibaren Hâlidîliğin önemli merkezlerinden biri haline gelmiştir. Mevlânâ Hâlid'in ilk halifelerinden Şeyh Osman Siracüddin et-Tavîlî (öl. 1283/1866) ve çocuklarının gayretiyle medrese-tekke modeline uygun olarak büyük bir ilim merkezine dönüştürülmüştür. Çoğunluğu Irak ve İran'da yaşayan pek çok ilim ve tasavvuf erbabı bu medresede yetişmiştir. Bk. Muhammed, Serbürdeki Havraman,1309; Abdülkerim Müderris, Ulemâunâ fî hidmeti'l-ilmi ve'ddîn (Bağdât: Dâru'l-Hurriyye, 1983), 25, 221, 325; Abdülkerim Müderris, Yâd-ı Merdân (Hevler: Çaphâne-I Ârâs, 2011), 2/9-32.

37 Arvas Medresesi on dördüncü yüzyılın ilk yarısının sonunda Van'ın Müküs (Bahçesaray) ilçesine bağlı Arvas köyünde kurulmuştur. Dönemin Hakkâri beylerinden İbrahim Han'ın desteğiyle kurulan bu medresenin ilk müderrisi ve mürşidi Seyyid Muhammed Kutub Arvasî olup, on dokuzuncu yüzyılın ilk çeyreğinde Sibğatullah Arvasî (öl. 1287/1870) ve Seyyid Fehim Arvasî (öl. 1313/1895) gibi bazı aile mensuplarının Seyyid Taha Hakkarî’ye (öl. 1269/1853) intisap etmeleriyle başlayan süreçte Hâlidî merkezine dönüşmüştür. Bk. M. Şefik Korkusuz, Nehri'den Hazne'ye Meşâyihi Nakşibendî̀ (İstanbul: Kilim Matbaacılık, 2010), 37; Kavak, Mevlânâ Hâlidi Nakşibendî, 381-382; Nimetullah Arvas, Seyyid Hâcı Kâsım Bă̆dadî'nin Nesebi, İcâzeti ve Seyahat Notları (İstanbul: Çınar Matbaacılık, 2020), 52-54.

38 Şeyh Aynü'l-Melek Medresesi, Muş'un Bulanık ilçesine bağlı Abrî (Esenlik) köyünde bulunmaktadır. Bu medresenin Abrî ailesi mensuplarından Şeyh Aynü'l-Melek adıyla meşhur Seyyid Nizameddin Abrî tarafından 725/1325 yılında cami, medrese, zaviye ve hamamdan oluşan bir külliye içinde yapıldı̆̆ı kaydedilir. Osmanlı devlet arşivi ve salnamelerde adı geçen bu medresede Osmanlı ve Cumhuriyet dönemlerinde etkili olmuş çok sayıda ilim ve tasavvuf erbabı eğitim görmüştür. Bk. Bitlis Vilayet Salnamesi (Bitlis: Bitlis Vilayet Matbaası, 1316/1898), 203; Mehmet Said Selvi, Mehmet Öztürk, Mehmet Sena Ekici, “Seyyid Aynü'l-Melek Hazretleri, Camisi, Vakfiyesi ve Muş Tarihindeki Yeri", Tarih ve Kültür Bağlamında Muş Uluslararası Sempozyum Bildirileri (Ankara: Atatürk Araştırma Merkezi Yay., 2019), 922.

39 Maverân Medresesi'nin adı Maveraünnehirden gelmektedir. Safeviyye tarikatı şeyhi Muhammed b. Haydar Pîruddin'in Şah İsmail'in zulmünden kaçan çocukları tarafından Kuzey Irak'ın Erbil şehrinde kurulmuştur. Irak ve İran'da çok meşhur olan Molla Abdullah Beytoşî (öl. 1210/1796) ve Molla Yahya Mizûrî (öl. 1252/1836) gibi şahsiyetler bu medresede yetişmiştir. İbrahim Fasih Haydarî (öl. 1299/1882) medreseyi kuran Haydarî ailesinden üç yüz alimin yetiştiğinden bahsettikten sonra bunların büyük bir kısmının Maveran Medresesinden icazetli olduklarını belirtir. Bk. İbrahim Fasîh Haydarî, 'Unvânü'l-mecd fî beyâni ahvâli Bă̆dat ve'l-Basra ve Necd (Beyrût: Dâru'l-Kutubi'l-'Illmiyye, 2010), 104; Abdulcebbar Kavak, Kuzey Irak'ta Tasavouf 17. Yüzyıl (Ankara: İlâhiyât Yay., 2016), 41-43.

40 Medresa Sor (Kırmızı Medrese) Molla Ahmed Cezerî (öl. 1050/1640) bu medresede müderrislik yapmıştır. Cizre ve çevresinden pek çok talebenin rağbet ettiği kadim medreseler arasında yer almaktadır. Bk. M. Sait Özervarlı, "Molla Cezerî", TDV İslam Ansiklopedisi (İstanbul: TDV Yay., 2005), 30/241.

41 Irak'ın İmadiye bölgesinde bulunan Kubbehân Medresesi, Kuzey Irak'ın en büyük medreselerinden biridir. On altıncı yüzyılda Behdînan Emîrlerinden Sultan Hüseyin bu medreseyi yaptırmış ve oğlu Kubad Han'ın adını vermiştir. Zamanla Kubbehân Medresesi olarak telaffuz edilmeye başlanmıştır. Bu medresenin aslında harabeye dönüşmüş bir dinî yapının temelleri üzerine yeniden inşa edildiği de rivayet edilmektedir. Kubbehân Medresesi geniş avlusu, kubbeli ve minareli mescidi, çok sayıda hoca ve talebe odaları, kütüphanesi, mahzeni ve hamamı, hayvan barınakları ve değirmeni ile pek çok talebeyi kendine cezbetmiş bir ilim merkezidir. Kürtçe(Kurmancî) Mevlid'in müellifi Molla Hüseyin Bateyî́nin (öl. 1163/1750) İmadiye'yi ziyareti sırasında Kubbehân Medresesinde kaldığından bahsedilir. Bk. Mesud Mustafa el-Kettânî, Medresetu Kubbehân (Erbil: Matbaatu Hâvâr, 2009), 1/19; İmâd Abdüsselâm Raûf, el-Mu'cemu't-târîhî li İmâreti Behdînân (Erbil: Matbaatu Hacı Haşim, 2011), 286-289; Dûskî, Feqî û Melâ, 28.

42 Hakkari'nin Şemdinli ilçesine bağlı Nehri beldesinde yer alan Nehri Medresesinin ilk olarak Seyyid Abdullah Şemdînî (öl. 1235/1819) döneminde şöhret bulduğu ifade edilir. Irak, İran ve Anadolu'dan çok sayıda talebenin rağbet ettiği bu medrese, on dokuzuncu yüzyılın ilk çeyreğinde kendileri de birer Hâlidî şeyhi olan Seyyid Abdullah Şemdînî ve yeğeni Seyyid Taha Hakkarî tarafından bir Hâlidî ilim ve irşad merkezine dönüştürülmüştür. Buradaki faaliyetler 1925 yılına kadar devam etmiştir. Bk. Korkusuz, Nehri'den Hazne'ye,1320; Mehmet Saki Çakır, Seyyid Tâhâ Hakkârî ve Nehrî Dergâhı (İstanbul: Nizamiye Akademi Yay., 2017), 29-30. 
Hâlidîliğin yayılmasıyla beraber nicelik olarak ciddi artış gösteren bu medreselerin toplumsal alandaki saygınlığı daha da pekişmiştir. Medreselerin halka yönelik faaliyetleri çeşitlenmiş, programları daha da zenginleşmiştir. Buralarda yetişen talebeler mezun olduklarında daha önce sadece ilmî kimlikleriyle görev alırken, Hâlidî şeyhlerinin tedrisatın başına geçmesinden sonra zülcenaheyn olarak yani hem alim hem de sûfî bir müderris olarak daha güçlü bir şekilde görev yapmaya başlamışlardır. Sadece ilim değil ahlak ve maneviyatı da öğreten ve bunu bizzat yaşayan canlı örnekler olarak yetişecek yeni nesillere rol model olmuşlardır. Tasavvufî faaliyetleri medresenin ilmî faaliyetleriyle mezceden Hâlidîler, her ikisini de camilere taşımak suretiyle sadece ibadete tahsis edilen camileri ibadet, ilim ve maneviyatla ihyâ ederek, halkın camilere olan ilgisini arttırmışlardır. Bu şekilde camiler yeniden toplumsal hayatın merkezine oturmaya başlamıştır. Burada yapılan zengin faaliyetlerle âtıl durumdaki pek çok mescid ve cami çocuk, genç ve yaşlılara hitap eden aktif entelektüel bir mekân haline gelmiştir.

\section{Sonuç}

Mevlânâ Hâlid-i Bağdadî'nin kurduğu Hâlidîlik, Nakşibendî-Müceddidî tasavvuf geleneğinin on dokuzuncu yüzyılda Ortadoğu'daki en başarılı temsilcisidir. Hâlidîliğin en bariz vasıflarından biri camilerle beraber medreseleri de ihyâ etmesidir. Mevlânâ Hâlid ve halifeleri ilk olarak Irak'ın Şehrezor bölgesi ile İran ve Anadolu'da yaşayan Kürtler arasında faaliyet yürütmeye başlamışlardır. Bu nedenle ilim ve tedrisat olarak ilk el attıkları kurumlar bu bölgelerde yaygın olan Şark Medreseleri olmuştur.

Nizamiye Medreselerinin devamı niteliğinde asırlardır faaliyet yürüten, ders müfredatında ilmî eserlerin Arapça, edebî eserlerin Farsça olduğu Şark Medreseleri, pek çok alim, mütefekkir ve şairin yetiştiği ilim merkezleri olmuştur. Talebelerinin büyük çoğunluğu Kürtlerden oluşan Şark Medreselerinde Arap, Türk ve İranlı talebeler de ilim tahsilinde bulunmuşlardır. Müderrisler genellikle dersleri Kürtçe takrir etmiş, talebeler de derslerin mütalaa ve müzakerelerini Kürtçe yapmışlardır.

Hâlidîlik, şeriat ve tarikat dengesini gözeten, ilim ve medreseyi önceleyen tasavvufî bir hareket olarak tarikatı şeriatle, tasavvuf ve tekkeleri de ilim ve medreselerle mezcetmiştir.

43 Norşin Medresesi Abdurrahman-1 Tağ̂i (öl. 1304/1886) tarafından tahminen 1875 yılında Bitlis'e bağlı Norşin (Güroymak) ilçesinde kurulmuştur. Cumhuriyet döneminde içinde Said-i Nursî'nin (öl. 1960) de yer aldiğ çok sayıda alim, mutasavvıf ve mütefekkir şahsiyet bu medreseden mezun olmuştur. Bk. Korkusuz, Nehri'den Hazne'ye, 90; İbrahim Baz, “Osmanlıdan Cumhuriyete Norşin Dergâhı ve Şeyh Abdurrahman-1 Tâğ $\hat{1}^{\prime}$, Tasavouf İlmi ve Akademik Araştırma Dergisi 34/2 (2014), 81-82; Çakır, Seyyid Tâhâ Hakkârî, 126-127. 
Tasavvufî faaliyetlerin medresedeki ilmî faaliyetlerle tevhidi, zaman zaman toplumsal alanda karşı karşıya gelen medrese ve tekkeler arasındaki soğukluğu giderdiği gibi bu iki kurumu ilim ve takvâ temeli üzerinde birbirine yaklaştırmıştır. Şark Medreselerinin bulunduğu coğrafya başta olmak üzere nicel olarak İslam dünyasında büyük bir artış gösteren Hâlidî Medreseleriyle "Müderris-sûfî" modeli yaygınlaşmış ve toplumda benimsenen bir kimlik haline gelmiştir. Hâlidî medreselerinde ders okuyan talebeler, henüz ilim tahsilinin başında iken tasavvufî bir atmosferle de tanışmış böylece "mürit-talebe" modeli oluşmuştur. Hâlidîler tasavvufî faaliyetleri, ilmî faaliyetlerle beraber medrese çatısı altında tevhid ettikten sonra bir adım daha ileri giderek bu iki faaliyeti çok yaygın olan camilere taşımışlardır. Bu sayede camiler, ibadetin yanında ilim ve tedrisat ve ahlak ve maneviyatla ilgili faaliyetlerin yapıldığ canlı, dinamik ve çok yönlü bir mekâna dönüşmüştür. Her caminin yanına inşa edilen ve daha çok "Hücre" olarak adlandırılan bu son derece mütevazı mekanlarla beraber, camiler ilim talebelerinden oluşan entelektüel bir cemaate kavuşmuş, talebeler de hem ibadet hem de tedrisat açısından uygun ve nezih bir ortama kavuşmuşlardır. Hâlidîlerin bu girişimleri sonucu şehirlerin dışında belde ve köylerde de medreseli-cami modeli yaygınlaşmıştır. Bu sayede şehirlerde yoğunlaşan ilmî ve tasavvufî faaliyetlerden taşra da nasibini almaya başlamıştır. Bu sayede pek çok belde ve köyde tedrisat yapılmıştır.

Hâlidîliğin yayılmasıyla beraber Şark Medreselerinin kurumsal yapısı daha sağlam ve burada görev yapan müderrisler toplumsal alanda daha etkin şahsiyetler haline gelmişlerdir. Hatta bunlardan ilmiye sınıfı veya aristokrat ailelere mensup olan bazı şahsiyetler, siyasî ve toplumsal hadiselerde öncü ve lider bir rol üstlenmiştir. Hâlidîlerin Şark Medreselerinin kurumsal yapısına en büyük etkisi tedrisat merkezli bu kurumları tedrisat ve irşad merkezli medrese-tekke modeline dönüştürmeleridir. Hâlidîler Şark Medreselerinin genel müfredatını değiştirmeden sadece içinde Mevlânâ Hâlid-i Bağdadî'nin Divan'ının da yer aldığı tasavvufî bazı manzum ve mensur eserler eklenmek suretiyle devam ettirmişlerdir. 


\section{Kaynakça}

Afîfî, Ebu'l-'Alâ. et-Tasavvuf es-sevretu'r-rûhiyye fi'l-İslâm. Beyrût: Dâru'ş-Şa'b, ts.

Aktepî, Abdürrahman el-. Ravdu'n-Na'îm. Diyarbakır: Mektebetu Seyda, 2010.

Algar, Hamid. Nakşibendîlik. çev. Cüneyd Köksal vd., İstanbul: İnsan Yay., 2013.

Argun, Yuca, Şaban. İrşad Sami. “Muş Bulanık Mollakent/Mellekend Medresesinden Bir Âlim

Portresi: Şeyh İhsan-ı Mellekendî'nin Hayatı ve İcâzetnâmesi”, e-Şarkiyat İlmi Araştırmalar Dergisi 11/1 (2019), 150-170.

Arvas, Nimetullah. Seyyid Hâcı Kâsım Bağdadî'nin Nesebi, İcâzeti ve Seyahat Notları. İstanbul: Çınar Matbaacılık, 2020.

Aşkın, Deniz. “Geleneğin Savunucusu: Türkiye'de Geleneksel Şark Medreseleri ve Müderrislerin (Seydaların) Modern Din Eğitimine Eleştirileri", Anemon Muş Alparslan Üniversitesi Sosyal Bilimler Dergisi 8/1 (2010), 9-17.

Ayiş, M. Şirin. "Bingöl Hâlidî Geleneğinin Medrese Boyutu". Bingöl Üniversitesi İlahiyat Fakültesi Dergisi 5/10 (2017), 71-94

Azzâvî, Abbas. “Hulefâu Mevlânâ Hâlid". Mecelletü'l-mecma'i'l-'ilmiyyi'l-Kürdî, (1974/2).

Azzâvî, Abbas. Zikrâ Ebi's-Senâ'l-Âlûsî. Bağdat: Şirketu't-Ticâreve't-Tibâ'a, 1958.

Bala, Sabahattin. Yitik Bir Miras Şark Medreseleri. İstanbul: Hiperyayın, 2019.

Baz, İbrahim. "Osmanlıdan Cumhuriyete Norşin Dergâhı ve Şeyh Abdurrahman-1 Tâğî". Tasavvuf Ilmi ve Akademik Araştırma Dergisi 34/2 (2014), 75-110.

Bitlis Vilayet Salnamesi. Bitlis: Bitlis Vilayet Matbaası, 1316/1898.

Çakır, Mehmet Saki. Seyyid Tâhâ Hakkârî ve Nehrî Dergâhı. İstanbul: Nizamiye Akademi Yay., 2017.

Çelebi, Ahmed. İslam'da Ĕ̆itim Öğretim Tarihi. çev. Ali Yardım İstanbul: Damla Yay., 1983.

Çiçek, M. Halil. Şark Medreselerinin Serencâmı. İstanbul: Beyan Yay., 2009.

Çokreşî̀, İbrahim. Kitâbü'l-İşârât, (Yazma nüsha fotokopisi).

Dûskî, Tahsin İbrahim. Feqî î Melâ û Medrese. Duhok: Weşânên Êkitiya Zanayên Âyinî İslamî, 2012.

Dündar, Mahmut. Mısır Eyyûbilerinde Ĕ̆itim ve Öğretim Faaliyetleri. İstanbul: Çıra Akademi Yay., 2017.

Epözdemir, Şakir. Medreseyên Kurdıstanê. İstanbul: Nûbihar Yay., 2015.

Eserî, Muhammed Behcet el-. A'lâmu'l-Irâk. Beyrût: ed-Dâru'l-Arabiyye Li'l-Mevsû'ât, 2002.

Gündüz, İrfan. Gümüşhanevî̀ Ahmed Ziyâüddin Hayatı- Eserleri-Tarîkat Anlayışı ve Hâlidiyye Tarîkatı. İstanbul: Seha Neşriyat, 1984.

Halaçoğlu, Yusuf. Osmanlılarda Devlet Teşkilatı ve Sosyal Yapı. Ankara: Türk Tarih Kurumu Yay., 2014.

Hamidî, Muhammed Sadık. “Doğu ve Güneydoğu Medreselerinin Mahiyeti ve Ders Müfredatının Islah Önerisi", Medrese Geleneği ve Modernleşme Sürecinde Medreseler Uluslararası Sempozyumu, ed. Fikret Gedikli, Muş: Muş Alparslan Üniversitesi Yay., 2013.

Haydarî, İbrahim Fasîh. 'Unvânü'l-mecd fì beyâni ahvâli Bă̆dat ve'l-Basra ve Necd. Beyrût: Dâru'lKutubi'l-'Illmiyye, 2010.

Hodgson, Marshall G.S. İslam'ın Serüveni. çev. Alp Eker vd. İstanbul: İz Yay., 1995.

Kara, Mustafa. Din Hayat Sanat Açısından Tekkeler ve Zaviyeler. İstanbul: Dergâh Yay., 1999.

Kavak, Abdulcebbar. Kuzey Irak'ta Tasavouf 17. Yüzyıl. Ankara: Illâhiyât Yay., 2016.

Kavak, Abdulcebbar. Mevlânâ Hâlid-i Nakşibendîve Hâlidîlik. İstanbul: Nizamiye Akademi Yay., 2016.

Kettânî, Mesud Mustafa el-. Medresetu Kubbehân. Erbil: Matbaatu Hâvâr, 2009. 
Korkusuz, M. Şefik. Nehri'den Hazne'ye Meşâyihi Nakşibendî. İstanbul: Kilim Matbaacılık, 2010.

Muhammed, Abdürrezzâk Abdurrahman. Serbürdeki Havraman Serdaneki Tavîle. Tahran: Çaphâne-1 Mahâret, 2005.

Müderris, Abdülkerim. Ulemâunâ fî hidmeti'l-ilmi ve'd-dîn. Bağdât: Dâru'l-Hurriyye, 1983.

Müderris, Abdülkerim. Yâd-ı Merdân. Hevler: Çaphâne-i Ârâs, 2011.

Nursî, Said. Mesnevî̀-i Nûriye. çev. Abdülmecid Nursî. İstanbul: Sözler Yay., 1977.

Özaydın, Abdülkerim. "Nizâmiye Medresesi”. TDV İslam Ansiklopedisi. İstanbul: TDV Yay., 2007.

Özer, Selim. "Modernleşme Sürecinde Geleneksel Dinî Gruplar: "İskenderpaşa Cemaati" Örneği”. Bursa Uludă̆ Üniversitesi Sosyal Bilimler Enstitüsü. Bursa: Doktora Tezi, 2018.

Özervarlı, M. Sait. “Molla Cezerî”. TDV İslam Ansiklopedisi. İstanbul: TDV Yay., 2005.

Özköse, Kadir. Libya'da Tasavvufî Hayat (Senûsiyye Tarikatı). Konya: Ensar Yay., 2008.

Öztoprak, Sadreddin. Şark Medreselerinde Bir Ömür. İstanbul: Beyan Yay., 2003.

Raûf, İmâd Abdüsselâm. el-Mu'cemu't-târîhî li İmâreti Behdînân. Erbil: Matbaatu Hacı Haşim, 2011.

Selefî, Hamdi Abdülmecid ed-Dûskî el-. Tahsin İbrahim. Mu'cemu'ş-şu'arâi'l-Kurd. Duhok: Dâru Spîrez, 2002.

Selvi, Mehmet Said. vd. “Seyyid Aynü'l-Melek Hazretleri, Camisi, Vakfiyesi ve Muş Tarihindeki Yeri", Tarih ve Kültür Bağlamında Muş Uluslararası Sempozyum Bildirileri, Ankara: Atatürk Araştırma Merkezi Yay., 2019.

Uslu, Hüseyin. Başlangıçtan Günümüze İslam Müesseseleri Tarihi. İstanbul: Gonca Yay., 1985.

Uzunçarşılı, İsmail Hakkı. Osmanlı Devleti'nin İlmiye Teşkilatı. Ankara: Türk Tarih Kurumu Yay., 2014. 